The American Journal of Agriculture and Biomedical Engineering (ISSN - 2689-1018)

VOLUME 04 ISSUE 01 Pages: 13-21

SJIF IMPACT FACTOR (2020: 5. 34) (2021: 5. 554)

OCLC - 1121105746 METADATA IF - 7.125

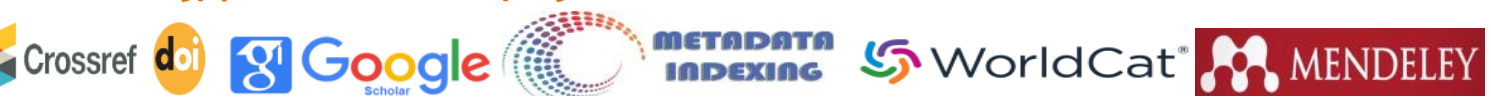

Research Article

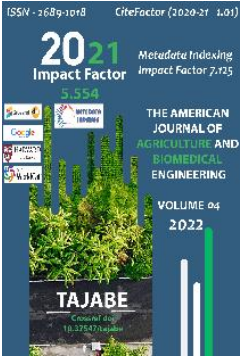

Journal Website: https://theamericanjou rnals.com/index.php/ta jabe

Copyright: Original content from this work may be used under the terms of the creative commons attributes 4.0 licence.

\section{ANATOMICAL STRUCTURE OF VEGETATIVE ORGANS OF MEDICINAL PLANTS PHYSALIS ANGULATA L. AND THEIR CHEMICAL COMPOSITION}

\author{
Submission Date: January 11, 2021, Accepted Date: January 20, 2022, \\ Published Date: January 30, 2022 | \\ Crossref doi: https://doi.org/10.37547/tajabe/Volume04Issue01-03
}

\section{M.M. Makhmudova}

S.Yu. Yunusov Institute of the Chemistry of Plant Substances Academy of Sciences, of Uzbekistan 100170, Mirzo Ulugbek Str., 77, Tashkent

\author{
I.D. Bobaev \\ Tashkent Chemical-Technological Institute, of Uzbekistan 100011, A. Navoiy Str., 32, Tashkent
}

\section{V.K. Sharipova}

Institute of Botany Academy of Sciences Republic of Uzbekistan

\section{V.N. Syrov}

S.Yu. Yunusov Institute of the Chemistry of Plant Substances Academy of Sciences, of Uzbekistan 100170, Mirzo Ulugbek Str., 77, Tashkent

\title{
ABSTRACT
}

The aim of the study is to obtain an extract of Physalis angulata germinating in Uzbekistan. Witanolides were isolated from the extract - fizangulide B, 14a-hydroxyixocarpanolide and other biologically active substances. Analysis of the anatomical structure showed that the leaves are dorsiventral, the stomatal apparatus is anocytic. Essential oil secretory receptacles and essential oil cells are observed in the leaf, petiole and root. The main morphological and anatomical characteristics of the raw plant Physalis angulata were revealed. Data on the microscopic structure of vegetative organs can also be used in the compilation of anatomical atlases of useful plants.

\section{KEYWORDS}

Physalis angulata, 14a-hydroxyixocarpanolide, 24,25-epoxyvitanolide D, vitanolide, fizangulide B, anatomy, leaf, stem, root. 
The American Journal of Agriculture and Biomedical Engineering (ISSN - 2689-1018)

VOLUME 04 ISSUE 01 Pages: 13-21

SJIF IMPACT FACTOR (2020: 5. 34) (2021: 5 · 554)

OCLC - 1121105746 METADATA IF - 7.125
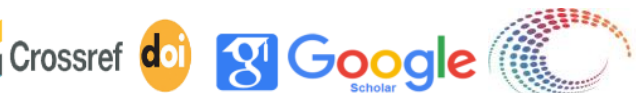

metapata

5. WorldCat 1 ใి MENDELEY

Publisher: The USA Journals

\section{INTRODUCTION}

Physalis L. is a genus of perennial, herbaceous or annual plants that are primarily native to tropical North and South America. Some species of Physalis are widespread in warmer parts of the world. The genus Physalis, which belongs to the Solanaceae family, numbers 90 to 120 species inhabiting tropical and temperate regions, most of which are found in America, and only a few species in Europe and Asia [1].

Physalis angulata is an herbaceous, annual plant from the Solanaceae family. Propagated by seeds. The leaves are dark green and almost oval, often with teeth along the edge. Flowers with fused five petals, at the top with triangular tips, pale yellow. The fruit is yelloworange inside the calyx and resembles a balloon, ribbed at the top of the ribs with purple stripes. Currently widespread and naturalized in tropical and subtropical regions around the world [2].

In folk medicine and modern pharmaceutical industry, widespread use has several pharmacological properties, such as anti-inflammatory [3, 4], immunosuppressive [5], immunomodulatory [6], antibacterial activity [7]. They are used as pain relievers, diuretics and antipyretics; used in the treatment of malaria, asthma, gonorrhea, liver disease, as well as diabetes, rheumatism, constipation, indigestion and intestinal disorders, wounds and skin diseases [8].

The first chemical study of the P. angulata, was carried out back in 1986. Amorphous substances named 14ahydroxyixocarpanolide and 24,25-epoxyvitanolide D were isolated from the leaves [9].

In the literature, there is no complete information on the anatomical structure of the vegetative organs of $P$. angulata, which could serve in the identification of the medicinal raw material of this plant, in connection with which the study of leaf anatomy and the identification of microdiagnostic features is relevant.

The purpose of this work was to identify the anatomical and morphological diagnostic signs of vegetative organs and their chemical composition of the medicinal plant P. angulata growing in different conditions of Uzbekistan for the identification of plant materials.

\section{MATERIALS AND METHODS}

During the microscopic examination, we used $P$. angulata plants collected during the flowering period. Fresh plant materials were fixed in 70 ? ethanol. Anatomical studies were carried out according to the generally accepted method [10]. Cross sections were prepared by hand with a razor. Micrographs were taken with a computer microphoto attachment with a Samsung digital camera.

In this regard, we continued our studies to study the chemical composition of the vitasteroids Physalis angulata L. We have made an extraction of the leaves of a plant growing in the territory of the Tashkent region. Isolation of withasteroids of the compound physangulide B (I) and 14a-hydroxyixocarpanolide (II) from the leaves of P. angulata, and the separation of the components into individual substances was carried out by column chromatography $[11,12]$.

Isolation of individual substances from the leaves of Physalis angulat Collected dried leaves (4 kg) of Physalis angulata L. were poured into cold water and heated to boiling. The hot mass was squeezed out through a canvas. The plant was again poured into cold water, heated, and the hot mass was squeezed out through the canvas again. The water extract was 
The American Journal of Agriculture and Biomedical Engineering (ISSN - 2689-1018)

VOLUME 04 ISSUE 01 Pages: 13-21

SJIF IMPACT FACTOR (2020: 5. 34) (2021: 5 · 554)

OCLC - 1121105746 METADATA IF - 7.125

\section{Crossref do
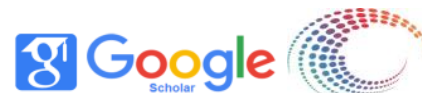 \\ metapenta \\ 5. WorldCat}

Publisher: The USA Journals

distilled until the volume decreased to $3 \mathrm{~L}$. Chloroform ( 3 L) was poured into the received solution and substances were extracted. From the chloroform layer, insoluble and soluble substances ( $25 \mathrm{~g}$ ) were isolated. To the isolated dry mass, $0.5 \mathrm{~L}$ of chloroform were added and the solution was filtered (the mass of the insoluble compounds was $5.8 \mathrm{~g}$ ). From the filtrate after distillation, $19.2 \mathrm{~g}$ of compounds were isolated. The compounds isolated from the filtrate were loaded onto a column containing $0.5 \mathrm{~kg}$ of silica gel (Silica gel 60, 0.063-0.1 mm, Merck). The sums of substances were eluted with system 1 (chloroform:methanol 99:1) to produce fractions 1-5, and eluted with system 2 (chloroform:methanol 97:3) for produce fractions 5-9. The process was monitored by thin layer chromatography (Silica gel on TLC Al foils, fluorescent indicator $254 \mathrm{~nm}$ ). Fractions 2-4 (6.8 g) and 6-8 (4.0 g) were shown by TLC to consist of individual substances [11].

Physangulide B, 14-hydroxyixocarpanolide, showed pronounced anti-inflammatory activity. In the first series of experiments, their efficacy was evaluated on a model of adjuvant arthritis, which was induced by sublantar injection of $0.1 \mathrm{ml}$ of Freund's complete adjuvant into the right hind paw of rats [4].

\section{RESULTS AND DISCUSSION}

$5.96 \mathrm{~g}$ of the individual product was isolated from rechromatography of fractions 2-4 containing physangulide $B$ in system 3 (chloroform:methanol 10:1). The $R f$ in system 3 was 0.58 , visualized as a crimson spot. The yield was $0.15 \%$, based on the weight of the air-dry raw material. The yield of 14? hydroxyixocarpanolide $3.6 \mathrm{~g}$ after rechromatography of fractions $6-8$ in system $1, \mathrm{Rf}=0.34$ in system 2 and visualized as a pink spot.

The melting points of the substances were determined on a Krüss melting Point meter M 5000 (Germany). NMR spectra were recorded on a Varian 600-MR instrument with an operating frequency of $600 \mathrm{MHz}$ for $1 \mathrm{H}$ in a deuterochloroform solution. TMS (o ppm) was used as an internal standard in the $1 \mathrm{H} \mathrm{NMR}$ spectra. In the $13 \mathrm{C}$ NMR spectra, the chemical shift of the solvent $\left(\mathrm{CDCl}_{3}+\mathrm{CD}_{3} \mathrm{OD}, 625.35 \mathrm{ppm}\right.$ relative to TMS) was used as an internal standard. Fertigplatten Kieselgel 60 "Merk" chromatographic plates were used for TLC, and a $10 \%$ solution of sulfuric acid in water was used to develop the plates [11].
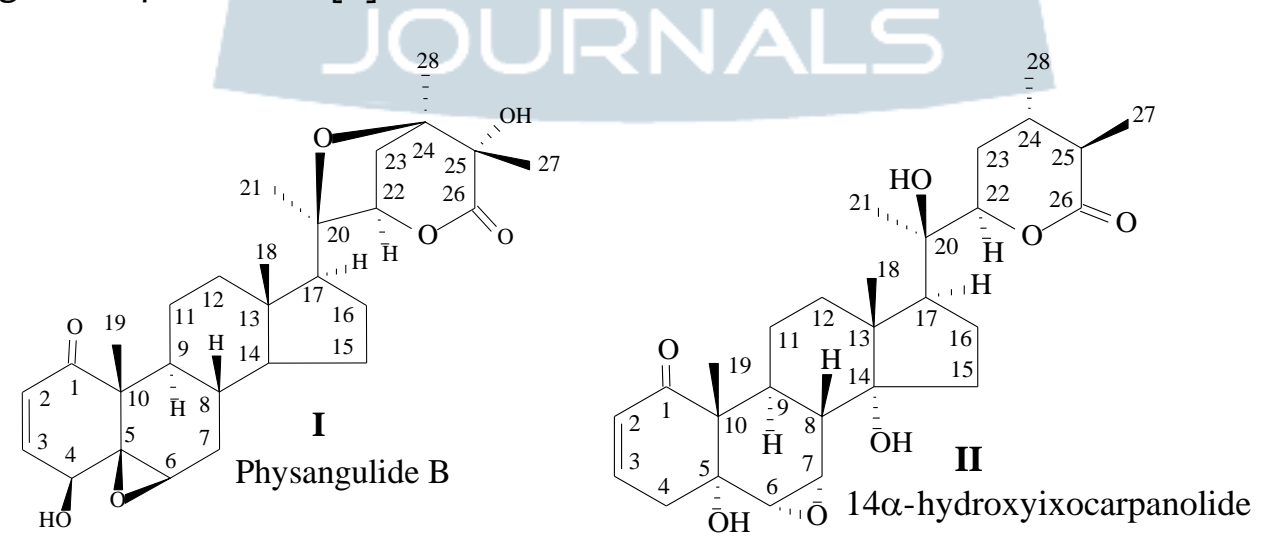
The American Journal of Agriculture and Biomedical Engineering (ISSN - 2689-1018)

VOLUME 04 ISSUE 01 Pages: 13-21

SJIF IMPACT FACTOR (2020: 5. 34) (2021: 5 · 554)

OCLC - 1121105746 METADATA IF - 7.125

\section{Crossref

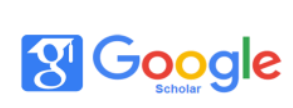

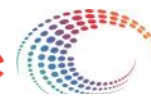

metapenta

5. WorldCat ${ }^{\circ}$ )ิ MENDELEY

Publisher: The USA Journals

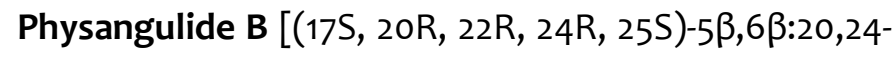
diepoxy-4 $\beta, 25$-dihydroxy-1-oxowith-2-en-26,22-olide)] (I). $\mathrm{C}_{28} \mathrm{H}_{40} \mathrm{O}_{7}$, m.p. $275-277^{\circ} \mathrm{C}$ (methanol), $[\alpha]^{20}{ }_{D}-56,0^{\circ}$ (c 0,21; chloroform); UV spectrum, $\lambda^{\mathrm{C}_{2} \mathrm{H}_{5} \mathrm{OH}}{ }_{\max }$ (Ig 5 5600) $212(4.00) \mathrm{nm}$. IR spectrum, $v^{\mathrm{KBr}}{ }_{\max }\left(\mathrm{cm}^{-1}\right): 3411(\mathrm{O}-\mathrm{H})$, $2958(\mathrm{C}-\mathrm{H}), 1706(\mathrm{C}=\mathrm{O}), 1676(\mathrm{C}=\mathrm{C}), 1457\left(\mathrm{CH}_{2}\right), 1380$ $\left(\mathrm{CH}_{3}\right), 1272-1177(\mathrm{C}-\mathrm{C}), 1101,1085,1024,962,921,905 \mathrm{~cm}$ ${ }^{1}[11]$.

14a-Hydroxyixocarpanolide (5a,14a,20R-trihydroxy-1oxo-6a,7a-epoxy-22R-witha-2-enolide) (II). m.p. 245$250^{\circ} \mathrm{C}$ (methanol), $[\alpha]^{20} \mathrm{D}+29,1 \pm 2^{\circ}$ (C 1,18; chloroform). nm. UV spectrum, $\lambda_{\text {max }}^{\mathrm{C}_{2} \mathrm{H}_{5} \mathrm{OH}} 225 \mathrm{~nm}(\varepsilon$ 10370). IR $v \mathrm{KBr}_{\max }\left(\mathrm{cm}^{-1}\right): 3584,3543,3477(\mathrm{O}-\mathrm{H}), 2981-2949(\mathrm{C}-\mathrm{H})$, 2866,1754 ( $\mathrm{C}=\mathrm{O}), 1692(\mathrm{C}=\mathrm{C}), 1458\left(\mathrm{CH}_{2}\right), 1388\left(\mathrm{CH}_{3}\right)$, 126-1182 (C-C), 1094, 1034, 978, 957, $910 \mathrm{~cm}^{-1}[11,12]$.

The introduction of physangulide $B$ to rats with adjuvant arthritis in a preventive and therapeutic regimen had a clear therapeutic effect, eliminating all pathological changes in the body and reducing the severity of inflammatory edema on both limbs: the right hind limb on the 3rd, 6th, 10th and 14th days of observation at $11.2 ; 25.2 ; 24.8$ and $27.4 \%$ compared with control, the volume of the left hind limb on the 14th day of observation was also $16.8 \%$ less than in rats in the control group. Physangulide $B$ exceeded the effect of prednisolone in terms of the severity of its antiinflammatory action $[3,4]$.

In the second series of experiments, the high antiinflammatory activity of the drug "Anguwit" developed on the basis of physangulide $B$, which is a $5 \%$ gel based on carbapol, was also shown [3].

$P$. angulata foliage is alternate. Leaflets pubescent with hairs, ovate-lanceolate, broadly lanceolate to oblong ovate. Leaf blade, 7-9 cm long, 4.5-6 cm wide, glabrous, beveled base, wavy edges, pointed apex.
The leaf is covered on the upper and lower sides with a single layer of epidermis. The outer walls of the leaf epidermis cells are strongly thickened, the main epidermal cells are slightly sinuous. The stomata are located on both sides of the epidermis, oval or round, anomocytic, with folded cuticle. The leaf structure is dorsiventral, characterized by the confinement of the columnar mesophyll to the upper side of the leaf blade (Fig. 1). Columnar mesophyll consists of two rows of tightly closed, rectangular-elongated cells. On the underside of the leaf there is a 3-4-row spongy mesophyll composed of loosely located oval thinwalled cells. In the mesophyll of the leaf, essential oil containers (idioblasts) were found, which are localized between the palisade and spongy parenchyma. The central vein protrudes from the abaxial side. It contains one large collateral conducting bundle with welldeveloped mechanical tissue. On both sides, under the epidermis, there are groups of collenchyme cells.

The petiole is rounded in cross section with a pronounced groove and lateral outgrowths rounded at the ends (Fig. 1).

Under the single-row epidermis of the petiole lies a multilayer parenchyma; its peripheral layers are differentiated into a lamellar collenchyma. Loose thinwalled parenchyma is behind collenchyma. In the middle part of the petiole - mesopetiole - there is one conductive bundle of an arcuate shape, not closed on the adaxial side. Above and below the bundle are areas of sclerenchyma. The conducting system is represented by a fan-shaped xylem, consisting of vessels and libriform cells. The phloem is narrow, encloses the xylem in the form of an arc and consists of elements characteristic of dicotyledonous plants. Cambium is not visible in the bunch. The receptacles in the leaf petiole are noted in the cells of the main tissue located closer to the mesophyll. 
The American Journal of Agriculture and Biomedical Engineering

(ISSN - 2689-1018)

VOLUME 04 ISSUE 01 Pages: 13-21

SJIF IMPACT FACTOR (2020: 5. 34) (2021: 5. 554)

OCLC - 1121105746 METADATA IF - 7.125

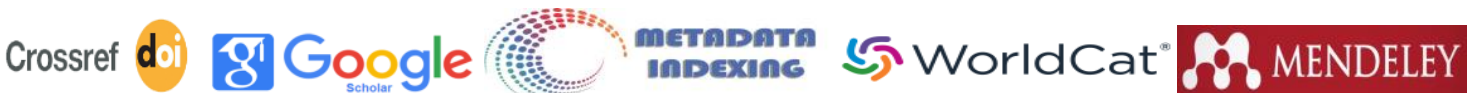

elongated in the tangential direction. Endoderm with

In cross-section, the stem is rounded-ribbed (Fig. 2). The integumentary tissue is a single layer of epidermis. The cells of the epidermis of the stem are polygonal, straight-walled. The primary cortex includes angular collenchyma, parenchyma, and endoderm. Angular collenchyma is located under the epidermis: in the ribs it is more powerful, consists of 3-5 layers of cells. The large-cell main parenchyma is located under the collenchyma. Its cells are thin-walled, rounded, slightly
Caspari belts. The central cylinder contains radially open bicollateral beams. On the periphery of the central cylinder there are 3-4 rows of sclerenchyma cells. The space between the bundles is filled with cells of the sclerenchyma and sclerefied parenchyma. Phloem conductive elements are represented by small thin-walled cells. Xylem vessels are rounded in cross section. 
The American Journal of Agriculture and Biomedical Engineering (ISSN - 2689-1018)

VOLUME 04 ISSUE 01 Pages: 13-21

SJIF IMPACT FACTOR (2020: 5· 34) (2021: 5. 554)

OCLC - 1121105746 METADATA IF - 7.125

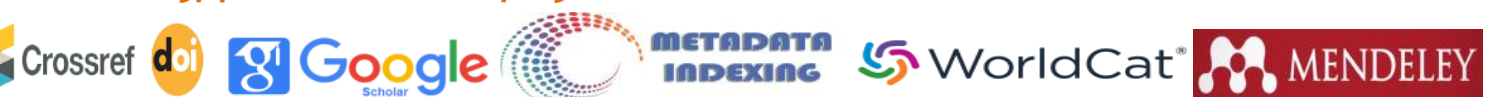
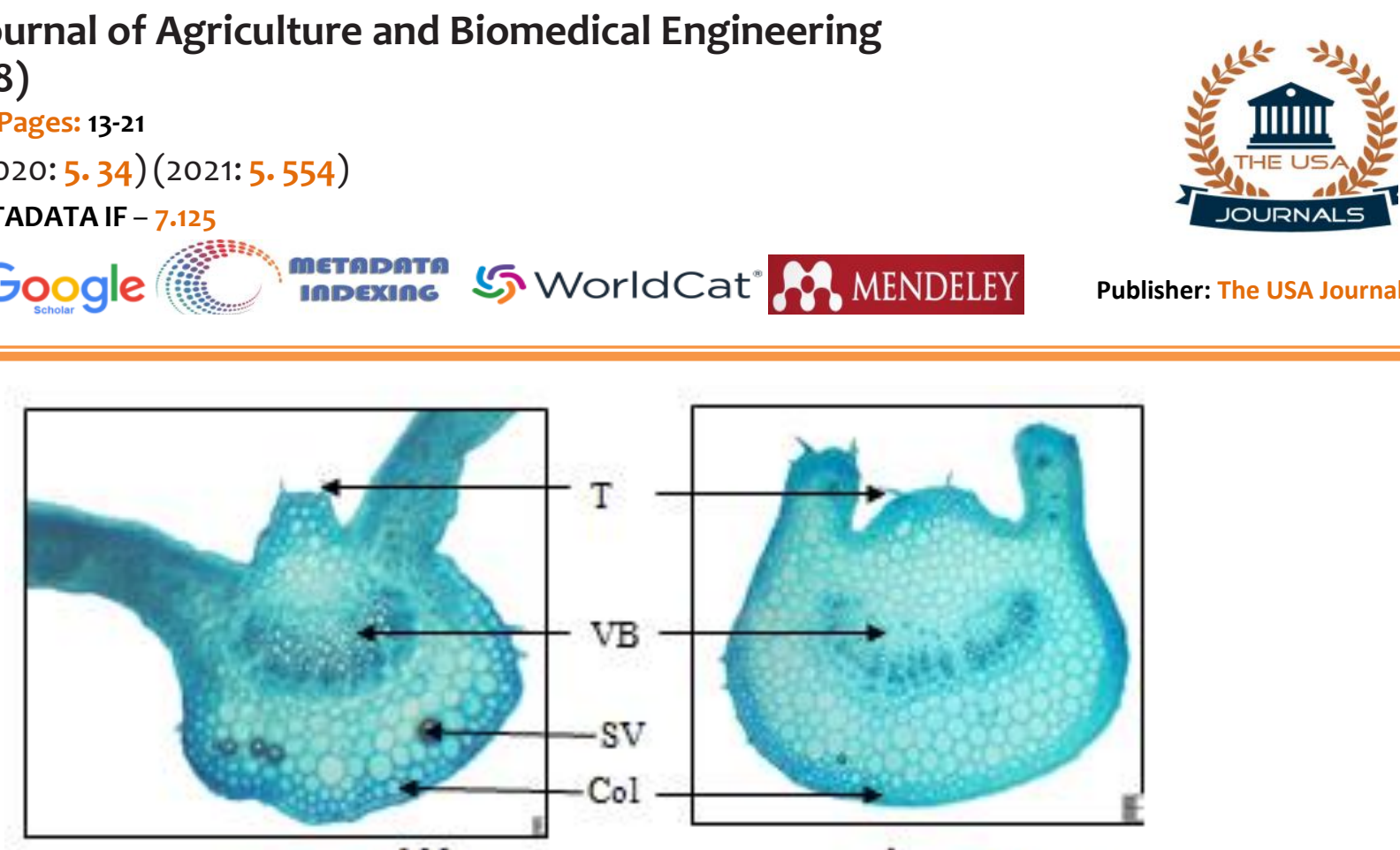

a $\quad 100 \mu \mathrm{m}$
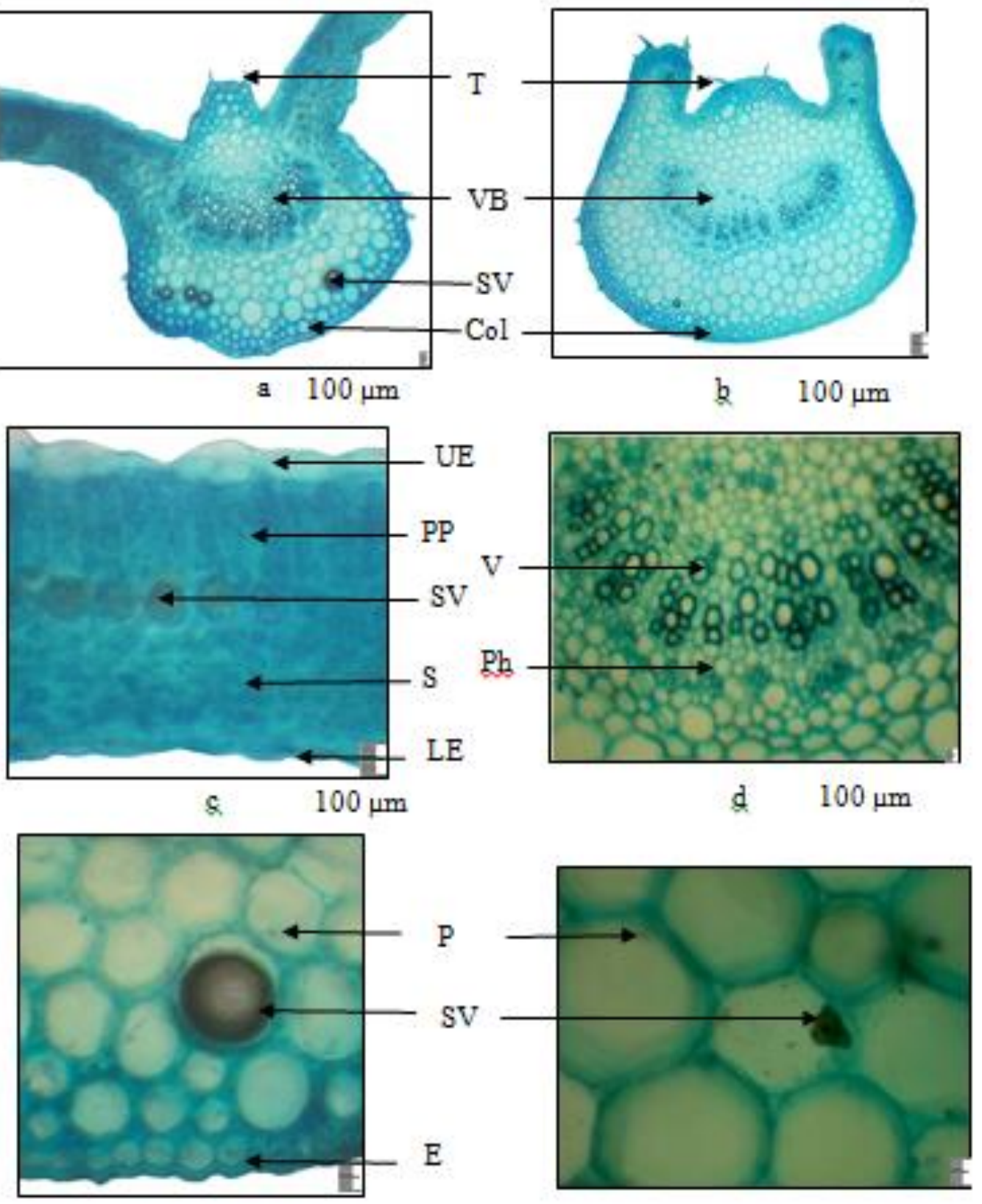

Fig. 1. Cross section of the leaf blade and petiole Physalis angulata: $a, b, c$ - leaf blade; $b, d, f$ - petiole. $a, b$ general view; c, e - mesophyll, d, e - median bundle of the petiole;

Legend: UE - upper epidermis, S - spongy parenchyma, Col - collenchyma, LE - lower epidermis, PP - palisade parenchyma, VB - vascular bundle, V - vessel, SV - essential oil secretory vittae, $\mathrm{T}$ - trichoma, $\mathrm{Ph}$ - phloem, E - epidermis. 
The American Journal of Agriculture and Biomedical Engineering (ISSN - 2689-1018)

VOLUME 04 ISSUE 01 Pages: 13-21

SJIF IMPACT FACTOR (2020: 5. 34) (2021: 5. 554)

OCLC - 1121105746 METADATA IF - 7.125

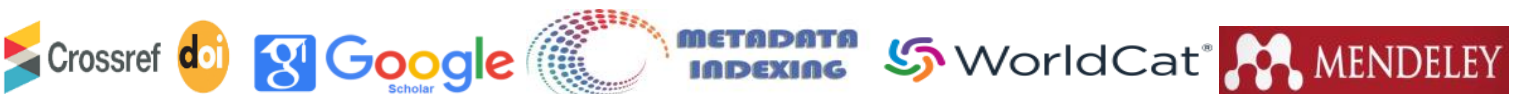

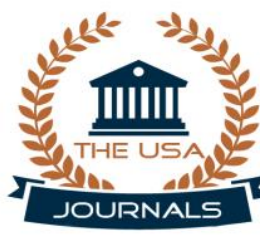

Publisher: The USA Journals

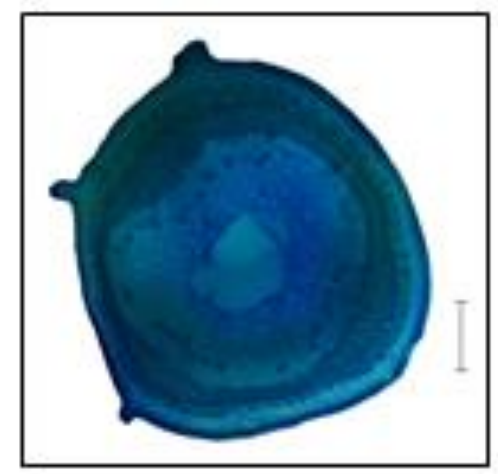

a. $\quad 1 \mathrm{~mm}$
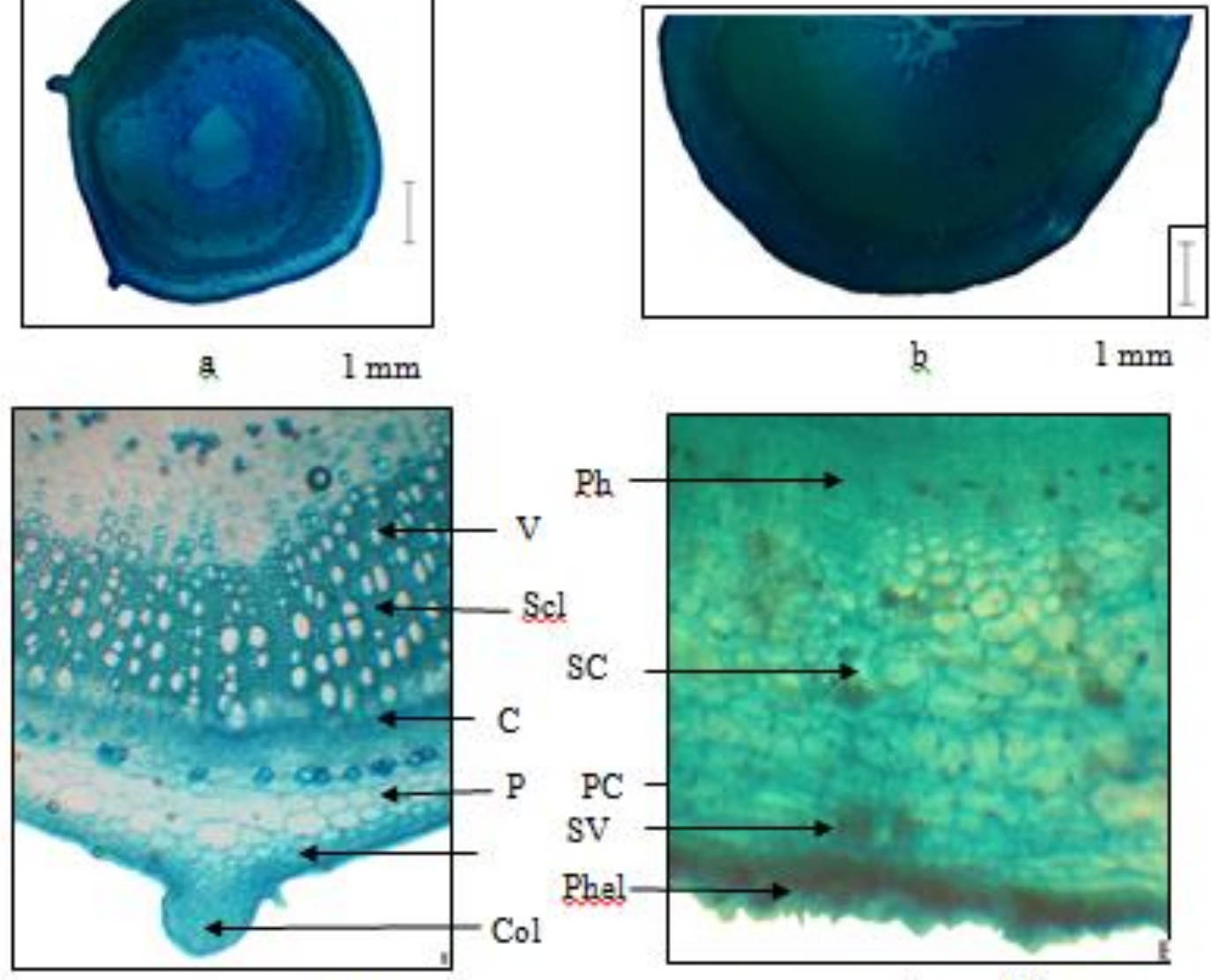

\&. $\quad 100 \mu \mathrm{m}$
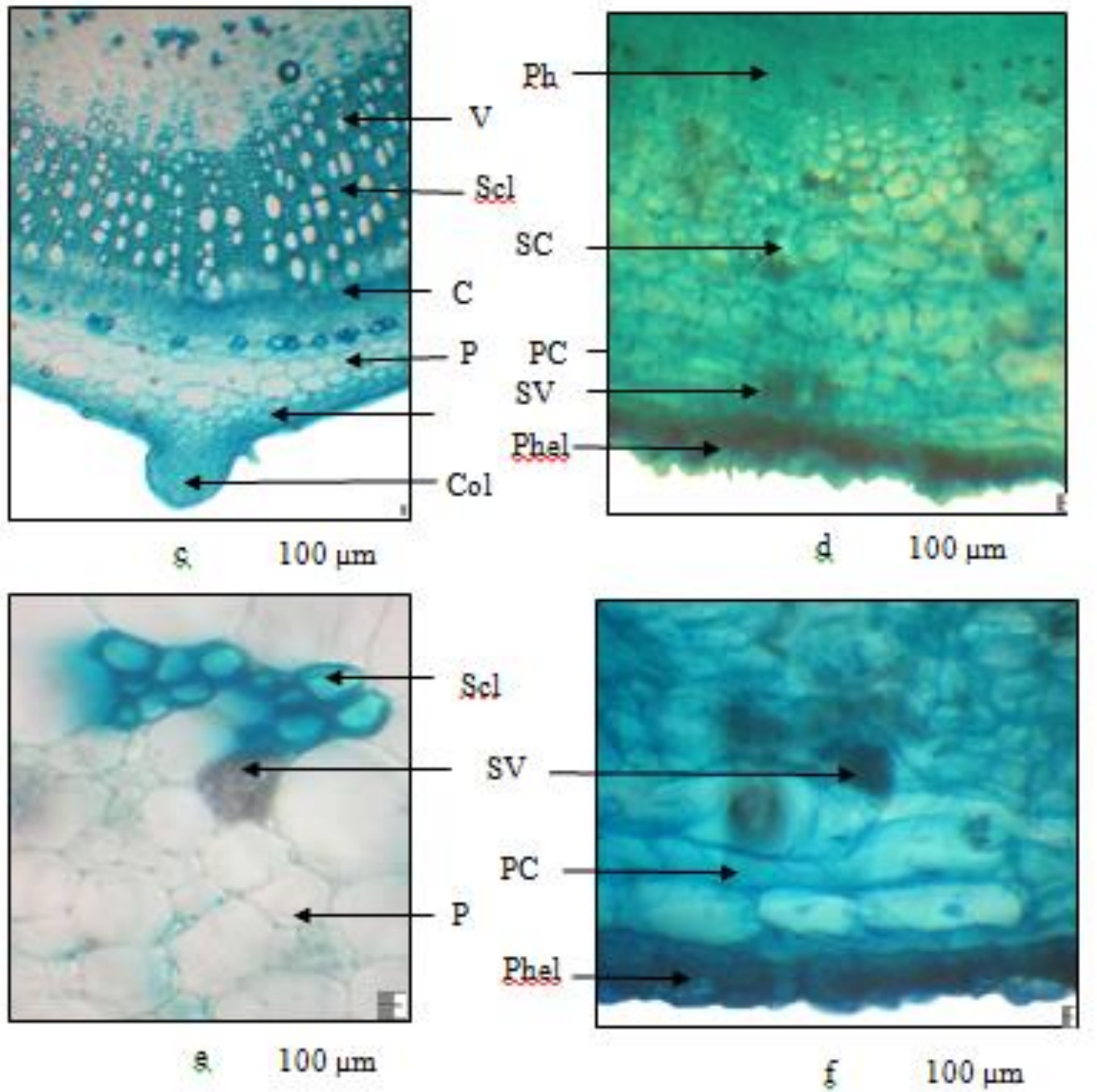

Fig. 2. Cross section of the stem and root of Physalis angulata: $a, b, c$ - stem; b, d, f - root. a, b - general view; c, $d, e, f$ - fragments. 
The American Journal of Agriculture and Biomedical Engineering (ISSN - 2689-1018)

VOLUME 04 ISSUE 01 Pages: 13-21

SJIF IMPACT FACTOR (2020: 5. 34) (2021: 5 · 554)

OCLC - 1121105746 METADATA IF - 7.125

Crossref do
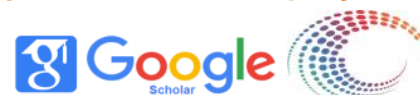

metapata

5. WorldCat

Publisher: The USA Journals

Legend: SC - secondary cortex, UE - upper epidermis, S - spongy parenchyma, C - cambium, Col - collenchyma, LE - lower epidermis, P - parenchyma, PC - primary cortex VB - vascular bundle, Phel - phelloderma, C vessel, $\mathrm{Scl}$ - sclerenchyma, $\mathrm{T}$ - trichoma

The parenchyma of the pith occupies a significant part of the central cylinder and consists of large, loosely located, thin-walled cells, enlarging towards the central part. Gradually, these cells are destroyed and a cavity is formed as a result. The outside of the root is protected by a cork. Under the cork is a multi-layered tissue with parenchymal cells. Further, the endoderm is clearly expressed (Fig. 2). The walls of the endoderm cell have uneven thickening. The pericycle consists of several layers and surrounds the parenchyma, penetrated by radial rays and conductive elements. Outside is the secondary and primary phloem. Sieve tubes are clearly visible in the phloem. Phloem cells provide organic matter necessary for root growth. The cell walls of the xylem are lignified. The xylem part is represented by reticular and scalene vessels with bordered pores, sclerenchymal fibers, and parenchymal cells. The cambium lies between the phloem and xylem parts. Multi-row radial rays extend from the cambium to the primary cortex. They are located towards the center of the root and abut against the vertices of the rays of the primary xylem, lignify. The air cavity is formed from the core cells, which consists of large thin-walled cells. Also in the roots, drops of yellow-golden essential oil are found in large quantities.

Thus, two known vitasteroids germinating in Uzbekistan were isolated from the plant Physalis angulaia L. One of them - Physangulide $B[(17 S, 20 R$,

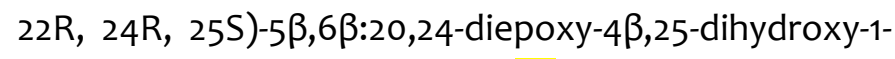
oxowith-2-en-26,22-olide)] (I) and another 14a- hydroxyixocarpanolide) (5a,14a,20R-trihydroxy-1-oxo6a,7a-epoxy-22R-witha-2-enolide) (II).

Analysis of the anatomical structure showed that the leaves are dorsiventral, the stomatal apparatus is anocytic. Essential oil secretory receptacles and essential oil cells are observed in the leaf, petiole and root. The data on the microscopic structure of the vegetative organs of $P$. angulata can also be used in the compilation of anatomical atlases of useful plants, the creation of keys for determining the taxonomic affiliation of species by anatomical features, in determining the authenticity of plants, standardization, as well as in carrying out complex pharmacognostic studies.

\section{ACKNOWLEDGMENTES}

This work was carried out as part of project - №20170927326 "Development of a domestic remedy with anti-inflammatory activity based on vitasteroids from plants of the genus Datura and Physalis" 2018-2020.

\section{REFERENCES}

1. Zang Z.Y., Lu A.M. "A Comparative study of Physalis, Capsicum and Tubocapsicum; Three Genera of Solanaceae" Eds. Solanaceae IV, Kent, WhitsableLitho Ltd., 1999. pp. 81-96.

2. Shishkin B.K., Bobrov E.G. Flora of the USSR. Publishing of the Academy of Sciences of the USSR. Moscow-Leningrad. - Volume. 22 .- P. 62-63.

3. Syrov V.N., Islamova Zh.I., Bobaev I.D., Vasina O.E., Khushbaktova Z.A. Angunolide and 4oxoangunolide as effective anti-inflammatory agents. Bulletin of the Tashkent Medical Academy. - 2018. - No. 1. - P. 39-46.

4. Syrov V.N., Khushbaktova Z.A. Islamova Zh.I., Makhmudova M.M., Egamova F.R., Yusupova S.M., Bobaev I.D. Comparative evaluation of the 
The American Journal of Agriculture and Biomedical Engineering (ISSN - 2689-1018)

VOLUME 04 ISSUE 01 Pages: 13-21

SJIF IMPACT FACTOR (2020: 5. 34) (2021: 5 · 554)

OCLC - 1121105746 METADATA IF - 7.125

anti-inflammatory efficacy of the vitasteroid fizangulide and prednisolone in conditions of adjuvant arthritis in rats. Journal. Infection, immunity and pharmacology. -Tashkent. - 2020. No. 3. - P. 161-166.

5. Vasina O.E., Abdullaev N.D., Syrov V.N., Khushbaktova Z.A., Sakhibov A.D., Abubakirov N.K. A method of obtaining vitasteriod with antiinflammatory and immunosuppressive activity. Certificate of autography U 1573574 A1. 20.07. 1988.

6. Silva B.M., Rodrigues A.P., Farias L.H., Hage A.A., Nascimento J., Silva E. Physalis angulata induces in vitro differentiation of murine bone marrow cells into macrophages. BMC Cell Biology. 2014; $15: 37$.

7. Silva M, Simas S, Batista T, Cardarelli P, Tomassini T. Studies on antimicrobial activity, in vitro, of Physalis angulata L. (Solanaceae) fraction and physalin B bringing out the importance of assay determination. Memorias do Instituto Oswaldo Cruz. 2005; 100: 779- 782.

8. Srivastava R., Yadav P.K. Preliminary phytochemical screening and TLC fingerprinting profile of Physalis angulate. The Pharma Innovation Journal, 2019, 8 (10), pp. 48-55.

9. Vasina O.E., Maslennikova V.A., Abdullaev N.D., Abubakirov N.K. Vitasteroids Physalis VII. 14ahydroxyixocarpanolide and 24,25-epoxyvitanolide D. // Chemistry of natural compounds Tashkent, 1986. - No. 5. - P. 596-602.

10. Barykina R.P., Chubatova N.V. A large workshop on the ecological anatomy of flowering plants. Moscow.: Tov-vo nauchn. ed. KMK; 2005: 77 p.

11. Okmanov R. Ya, Makhmudova M. M., Bobaev I. D., Tashkhodjaev B. Wlthanolides Physalis angulata $L$ I/ Acta Crystallographica Section E. England. - 2021.

- E77. - P. 804-808. doi.org/10.1107/S205698902100709X.
12. Makhmudova M.M., Bobaev I.D., Abduraxmonov B.A. Isolation and indentification of witasteroids from Physalis angulata leaves $/ 14^{\text {th }}$ international Symposium on the Chemstry of Natural Compounds. - Tashkent. - October 7-8. 2021.- P.53. 